\title{
Elimination of Tritium-Labelled Hyaluronic Acid from Normal and Osteoarthritic Rabbit Knee Joints ${ }^{1}$ )
}

\author{
Klaus Lindenhayn, Hans-Hubert Heilmann, Thorsten Niederhausen, Hans-Ullrich Walther and Kristina Pohlenz
}

Forschungsabteilung der Orthopädischen Klinik, Universitätsklinikum Charité, Humboldt-Universität zu Berlin, Berlin, Germany

Summary: The half-life of $\left[{ }^{3} \mathrm{H}\right]$ hyaluronic acid in rabbit knee joints was estimated using two methods:

(i) by following the $\left[{ }^{3} \mathrm{H}\right]$ hyaluronan content of the synovial fluid after intra-articular injection and

(ii) by following the ${ }^{3} \mathrm{H}_{2} \mathrm{O}$ radioactivity of plasma after intra-articular injection of $\left[{ }^{3} \mathrm{H}\right]$ hyaluronan.

For normal rabbits we obtained a half-life of 15.8 hours (method I) and $17.5 \pm 1.0$ hours (mean \pm SEM, method II), respectively. The second method was used to estimate the kinetics of the hyaluronan elimination from normal, sham-operated, as well as from osteoarthritic rabbit knee joints (Colombo model of osteoarthritis). Four weeks after injury, during the developing phase of osteoarthritis, the half-life of hyaluronan rose significantly to $23.5 \pm 2.1$ hours and returned to normal levels (17.4 \pm 2.7 hours) 12 weeks after the operation (osteoarthritis developed). At the stage of developed osteoarthritis, the clearance rates were considerably higher than in normal rabbits.

\section{Introduction}

Hyaluronic acid (hyaluronan) is a high molecular mass component of the synovial fluid that is responsible for its unique viscoelasticity as well as for other specific properties. Synovial fluid fulfills several physiological protective functions in the joint cavity such as shock absorption, traumatic energy dissipation and storage, radical scavenging and the protective coating of the articular cartilage surface and of the inner lining of the synovium, as well as controlling the "traffic" between the synovial vessels and the cartilage by an exclusion effect on migrating cells and larger molecules (1). Recently, repeated intra-articular injections of hyaluronan have been widely used in the treatment $(1-4)$ of osteoarthritis.

Hyaluronan of the synovial fluid is synthesized by lining cells and leaves the joint cavity via the lymphatic system $(5-7)$. The mean intrasynovial half-life of hyaluronan in rabbits has been found with high molecular mass $\left[{ }^{3} \mathrm{H}\right]$ hyaluronic acid $\left(M_{\mathrm{r}}>6 \times 10^{6}\right)$ to be 13.2 hours and with $\left[{ }^{3} \mathrm{H}\right]$ hyaluronic acid of lower $M_{r}\left(0.09 \times 10^{6}\right)$ to be 10.2 hours (6). After entering the circulation, it is quickly cleared from the blood by the sinusoidal endothelial cells of the liver $\left(t_{1 / 2}=2.5-4.5 \mathrm{~min},(8,9)\right)$. Therefore, the concentration of hyaluronan in serum is several orders of magnitude lower $(30-40 \mu \mathrm{g} / 1,(7,10))$

\footnotetext{
1) This work is part of a project which was supported by grants (01ZU9102) from the Bundesminister für Forschung und Technologie, Germany
}

than in synovial fluid $(3 \mathrm{~g} / \mathrm{l})$. In osteoarthritis the synovial fluid in general is more abundant and less viscous, whereas the concentration of hyaluronan is decreased and its molecular mass is reduced (2). The content of hyaluronan in the joint is elevated, because the volume of synovial fluid is enhanced in osteoarthritis (11). These alterations severely impair the physiological functions of the synovial fluid. In osteoarthritic synovium from dogs an enhanced rate of hyaluronan synthesis has been described $(12,13)$. It has not been reported whether the elimination rate of hyaluronan from the joint is changed under osteoarthritic conditions. Therefore, we have estimated the intrasynovial half-life of biochemically synthesized $\left[{ }^{3} \mathrm{H}\right]$ hyaluronic acid using the osteoarthritis model of Colombo et al. (14). Using an experimental model it is possible to measure the half-life of hyaluronan at different stages of the osteoarthritic process and to answer the question whether the determination of hyaluronan elimination rates of injured knee joints may be useful for the early diagnosis of osteoarthritis.

\section{Materials and Methods}

Animals

Nineteen chinchilla rabbits, weighing 2.7 to $3.2 \mathrm{~kg}$, were randomly divided into four groups: non-operated control animals $(n=5)$, sham-operated animals $(n=3)$, osteoarthritis group " 4 weeks after operation" $(n=5)$ and osteoarthritis group " 12 weeks after operation" $(n=6)$. In the osteoarthritis groups the fibular collateral and sesamoid ligament of the left knee were dissected and 4-5 mm of the anterior lateral area of the exposed meniscus was removed (14). In the sham-operated group the joint cavity was opened, the patella dislocated, as in the case of operation, and then reset. Finally the 
joint capsule and skin were sutured. Colombo et al. (14) only cut the skin in the sham-operated group.

For operation the animals were anaesthetized with $50 \mathrm{mg} / \mathrm{kg}$ ketamine (Ketanest ${ }^{\circledR}$, Parke-Davis) and $5 \mathrm{mg} / \mathrm{kg}$ xylazin (Rompun vet. ${ }^{\circledR}$, Bayer).

\section{Histology}

After sacrifice both femur condyles were excised, fixed in $100 \mathrm{~g} / 1$ formalin in $0.05 \mathrm{~mol} / 1$ phosphate buffer $(\mathrm{pH} \mathrm{7.2)}$ containing $5 \mathrm{~g} / 1$ cetyl trimethylammonium bromide, decalcified with $50 \mathrm{~g} / 1$ nitric acid and sections stained with haematoxylin/eosin and according to Masson-Goldner's method (15), respectively.

Synovium harvested together with both the joint capsule and patella was fixed in Kryofix ${ }^{\circledR}$ (Merck 5211) and embedded in paraffin after decalcification with $50 \mathrm{~g} / \mathrm{l}$ nitric acid.

\section{Harvesting of synovial fluid by the dilution method $(11,16)$}

The animals were anaesthetized with thiopental-Na (Trapanal ${ }^{\circledR}$, Byk Gulden, Germany) and received a $2.0 \mathrm{ml}$ intra-articular injection of $5 \mathrm{~g} / 1$ hydroxyethyl starch (average relative molecular mass 200000 , Fresenius AG, Bad Homburg) in saline. After passive motion of the joint for $5 \mathrm{~min}$ the mixture of hydroxyethyl starch solution and synovial fluid was aspirated. From the difference in the hydroxyethyl starch concentration between the injected hydroxyethyl starch (HES) solution and aspirated mixture, the volume of the synovial fluid and dilution factor of the aspirated mixture were calculated:

volume of synovial fluid $=$

volume of injected HES solution $\times$ difference in HES concentration

HES concentration of the aspirated mixture

dilution factor

$=\frac{\text { HES concentration of the injected HES solution }}{\text { difference in HES concentration }}$

\section{Determination of hydroxyethyl starch}

The hydroxyethyl starch concentration of joint aspirates was determined as described for "depot glucose" in 1.c. (16). Briefly, 100 $\mu \mathrm{l}$ test solution and $20 \mu \mathrm{l} 420 \mathrm{~g} / \mathrm{KOH}$ were heated in a small test tube (diameter $11 \mathrm{~mm}$, length $100 \mathrm{~mm}$ ) in boiling water for $5 \mathrm{~min}$. After cooling, $50 \mu \mathrm{l} 20 \mathrm{~g} / \mathrm{l} \mathrm{Na} \mathrm{SO}_{4}$ solution and $1 \mathrm{ml} 96 \%$ alcohol $(0.960 \mathrm{1} / 1$, volume fraction 0.96$)$ were added and the tubes kept at $6^{\circ} \mathrm{C}$ over night. After centrifugation at $2200 \mathrm{~g}$ for $10 \mathrm{~min}$, the precipitate was washed with $500 \mu \mathrm{l}$ of $80 \%$ alcohol $(0.8 \mathrm{l} / \mathrm{l}$, volume fraction 0.8$)$, dried and mixed with $2.5 \mathrm{ml} 0.6 \mathrm{~mol} / 1 / \mathrm{HCl}$. The tubes were sealed and heated in boiling water for 5 hours. The acid hydrolysate $(400 \mu \mathrm{l})$ was neutralized in a small test tube by adding $100 \mu \mathrm{l}$ of a saturated $\mathrm{KHCO}_{3}$ solution. The developing $\mathrm{CO}_{2}$ was eliminated by vigorous shaking. The glucose concentration of the neutralized hydrolysate was determined using the Test Kit "Glucose-Test 180" (Fermognost, Feinchemie Sebnitz GmbH, Germany) according to the manufacturer's instructions. The intra- and inter-assay coefficients of variation of the hydroxyethyl starch determination were $1.2 \%$ and $2.0 \%$, respectively.

\section{Biosynthesis of $\left[{ }^{3} \mathrm{H}\right]$ hyaluronic acid $(6,8)$}

After sacrifice, 4 normal rabbit knee joints were sluiced twice by intra-articular injection of $2 \mathrm{ml}$ phosphate buffered saline. Afterwards $2 \mathrm{ml}$ of a $5 \mathrm{~g} / 1$ solution of trypsin $(1: 250)$ in Leibovitz L-15 medium were injected into each knee joint and aspirated after $15 \mathrm{~min}$. This treatment was repeated two times. Finally the knee joints were sluiced with $3 \mathrm{ml}$ phosphate buffered saline. Fetal calf serum was added to the pooled trypsin solutions and the last wash (volume fraction 0.05 ). The cells were collected, seeded at a density of $53 \times 10^{3} / \mathrm{cm}^{2}$ and cultivated with Dulbecco's modified Eagle's medium (DMEM) containing $0.5 \mathrm{mmol} / 1$ cysteine and fetal calf serum (volume fraction 0.2 ). For biosynthesis the first subcul- ture of the cells was used. After the cells reached confluence the medium was changed to DMEM containing $0.5 \mathrm{mmol} / 1$ cysteine, $0.9 \mathrm{mmol} / 1$ glucosamine hydrochloride, $1.85 \mathrm{GBq} /{ }^{3} \mathrm{H}$-labelled sodium acetate (DuPont, Germany) and fetal calf serum (volume fraction 0.1 ). The medium ( $15 \mathrm{ml}$ per dish, $13.5 \mathrm{~cm}$ diameter) was changed every two days. All solutions contained $10^{5} \mathrm{IU} / 1$ penicillin, $100 \mathrm{mg} / 1$ streptomycin and $0.5 \mathrm{mg} / 1$ amphotericin. The media were pooled, concentrated and freed from excessive ${ }^{3} \mathrm{H}$-labelled sodium acetate by ultrafiltration.

$\left[{ }^{3} \mathrm{H}\right]$ Hyaluronic acid was isolated from the concentrated medium by density gradient centrifugation $\left(135000 \mathrm{~g}, 60 \mathrm{~h}, 4^{\circ} \mathrm{C}\right)$ in associative and dissociative conditions as described by Fraser et al. (8). Proteins originating from fetal calf serum were eliminated by the centrifugation in associative conditions $(1.505 \mathrm{~kg} / \mathrm{l} \mathrm{CsCl})$, whereas link proteins, hyaluronic acid, and proteoglycan subunits were separated by centrifugation in dissociative conditions $(4 \mathrm{~mol} / \mathrm{l}$ guanidinium hydrochloride, $\mathrm{CsCl}, 1.455 \mathrm{~kg} / \mathrm{l}$ ). Link proteins assemble in the upper part of the tube, hyaluronic acid in the middle zone $(1.425$ to $1.46 \mathrm{~kg} / \mathrm{l})$ and proteoglycan subunits in the lower part of the tube. The hyaluronan contained in the middle zone was isolated and centrifuged again in dissociative conditions. $\mathrm{CsCl}$ and guanidinium hydrochloride of the $\left[{ }^{3} \mathrm{H}\right]$ hyaluronan solution were eliminated by ultrafiltration. It has to be taken under consideration that hyaluronan is easily adsorbed on the ultrafiltration membrane. While concentrating $\left[{ }^{3} \mathrm{H}\right]$ hyaluronan solutions with aid of microconcentrators (Centricon-10, Amicon), the hyaluronan concentration of the solution did not rise, since the hyaluronan of the filtered solution was adsorbed on the membrane. After filtration, the gellike hyaluronan (filtercake) had to be solubilized by stirring with a small magnetic stirring bar. Levick et al. made similar observations when filtering hyaluronan solution through a $0.45 \mu \mathrm{m}$ Millipore membrane (17).

Using $143 \mathrm{~cm}^{2}$ of confluent synovial cells, we obtained $1804 \mu \mathrm{g}$ $\left[{ }^{3} \mathrm{H}\right]$ hyaluronic acid from $253 \mathrm{MBq}{ }^{3} \mathrm{H}$-labelled sodium acetate. The ${ }^{3} \mathrm{H}$ activity of the solution was $200 \mathrm{MBq} / \mathrm{l}$, the specific activity $1.3 \mathrm{TBq} / \mathrm{kg}$ hyaluronan. The labelled material was shown to be $96.4 \%$ hyaluronan by degradation with hyaluronidase from Streptomyces hyalurolyticus and chromatography in Sephadex G-50.

\section{Measurement of hyaluronan concentration}

The concentration of hyaluronan was determined using the thiobarbituric acid method (18) after enzymatic digestion of the samples with hyaluronidase from Streptomyces hyalurolyticus nov. sp. (Calbiochem, EC 4.2.99.1). This enzyme specifically cleaves hyaluronan to unsaturated oligosaccharides which were quantified by reaction with thiobarbituric acid (18). Chondroitin sulphate, chondroitin, heparin, keratan sulphate, and chitin were not degraded by this hyaluronidase (19).

Briefly, $50 \mu 1$ joint aspirate (mixture of hydroxyethyl starch and synovial fluid) containing between 0.2 and $1.0 \mathrm{~g} / \mathrm{l}$ hyaluronan were incubated with $50 \mu 10.04 \mathrm{~mol} / \mathrm{l}$ sodium acetate buffer $(\mathrm{pH} 5.2)$ and $50 \mu \mathrm{l}$ hyaluronidase $\left(10^{5}\right.$ turbidity-reducing units $\left./ \mathrm{l}\right)$ in $0.4 \mathrm{~mol} / 1$ sodium acetate buffer ( $\mathrm{pH} \mathrm{5.2)}$ at $60^{\circ} \mathrm{C}$ for $3.5 \mathrm{~h}$. For each aspirate an own blank was prepared $(50 \mu \mathrm{l}$ aspirate, $50 \mu \mathrm{l} 0.04 \mathrm{~mol} / \mathrm{l}$ sodium acetate buffer $\mathrm{pH} 5.2,50 \mu \mathrm{l} 0.4 \mathrm{~mol} / 1$ sodium acetate buffer $\mathrm{pH}$ 5.2). The assay was performed as described by Jourdian et al. (18). The absorbance of the butanol layer was determined at $552 \mathrm{~nm}$. Recovery of hyaluronan upon addition to aspirates was $98 \%$. The intra- and inter-assay coefficients of the hyaluronan determination were $1.06 \%$ and $1.9 \%$, respectively. Hyaluronan was dissolved in hydroxyethyl starch solution for establishing the standard curve.

To evaluate the thiobarbituric acid method, the hyaluronan concentration of the joint aspirates was also quantified using the radiometric assay of Pharmacia $\mathrm{AB}$ (Uppsala, Sweden). The correlation between the methods was very high (correlation coefficient $r=0.98$ ).

Estimation of half-life of hyaluronan by following the ${ }^{3} \mathrm{H}$ content of the joint fluid after intra-articular injection of $\left[{ }^{3} \mathrm{H}\right]$ hyaluronic acid (method $\mathrm{I}$ )

Three normal rabbits received an intra-articular injection of 0.475 $\mathrm{ml}\left[{ }^{3} \mathrm{H}\right]$ hyaluronic acid $(12 \mathrm{kBq}, 9.6 \mu \mathrm{g}$ hyaluronan) into their right 
Tab. 1 Elimination of $\left[{ }^{3} \mathrm{H}\right]$ hyaluronan from normal rabbit knee joints (method I).

Each of the three rabbits received an intra-articular injection of $\left[{ }^{3} \mathrm{H}\right]$ hyaluronan into the right knee joint. Synovial fluid was harvested by the dilution method after the indicated time, and ${ }^{3} \mathrm{H}$ ac- tivity was measured. Amount of intra-articularly injected $\left[{ }^{3} \mathrm{H}\right]$ hyaluronan: $9.6 \mu \mathrm{g}$. Hyaluronan content of normal rabbit knee joints: $910 \pm 90 \mu \mathrm{g}$ (mean $\pm \mathrm{SEM}), \mathrm{n}=6$. Clearance $=\mathrm{k}_{\mathrm{HA}} \cdot$ distribution volume. For the value of $\mathrm{k}_{\mathrm{HA}}$ see table 2 .

\begin{tabular}{lllll}
\hline Time after injection & $\begin{array}{l}\text { Volume of } \\
\text { synovial fluid } \\
{[\mu \mathrm{l}]}\end{array}$ & $\begin{array}{l}{ }^{3} \mathrm{H} \text { Radioactivity of } \\
\text { synovial fluid } \\
{[\mathrm{kBq} / \mathrm{l}]}\end{array}$ & $\begin{array}{l}{\left[{ }^{3} \mathrm{H}\right] \text { Hyaluronan }} \\
\text { content } \\
{[\mathrm{Bq} / \mathrm{joint}]}\end{array}$ & $\begin{array}{l}\text { Clearance }^{\mathrm{a}} \\
{[\mu \mathrm{l} / \mathrm{h}]}\end{array}$ \\
\hline 12.00 & 688 & 10384 & 7146 & 30.0 \\
24.25 & 590 & 6903 & 4073 & 25.8 \\
48.00 & 1003 & 1464 & 1469 & 43.8 \\
\hline
\end{tabular}

a These clearance values are higher than those in table 2 because the synovial fluid volume was augmented through the intra-articular injection of $475 \mu\left[{ }^{3} \mathrm{H}\right]$ hyaluronan solution.

knee joints. Synovial fluid from the first rabbit was harvested 12 hours after injection, from the second one after 24 hours and from the third one after 48 hours. Before mixing with the scintillator the joint fluids had to be digested by hyaluronidase. Without this preceding digestion, the hyaluronic acid slowly precipitates and no reproducible count rates will be obtained. The total activity of $\left[{ }^{3} \mathrm{H}\right]$ hyaluronic acid of the synovial fluid can be calculated, because the dilution factor of the aspirated mixture and volume of synovial fluid are obtained by the dilution method.

Estimation of half-life of hyaluronan by measuring ${ }^{3} \mathrm{H}_{2} \mathrm{O}$ radioactivity in blood (6) after intra-articular injection of $\left[{ }^{3} \mathrm{H}\right]$ hyaluronic acid (method II)

A solution $(0.44$ to $0.60 \mathrm{ml})$ of $\left[{ }^{3} \mathrm{H}\right]$ hyaluronic acid $(68-92 \mu \mathrm{g}$ hyaluronan, $88-120 \mathrm{kBq}$ ) in phosphate buffered saline containing $10^{5} \mathrm{U} / 1$ penicillin, $0.1 \mathrm{~g} / 1$ streptomycin and $0.5 \mathrm{mg} / 1$ amphotericin was injected into each left knee joint with a needle of $0.6 \mathrm{~mm}$ diameter inserted through the patellar ligament. For injection the animals were briefly anaesthetized with thiopental-Na (Trapanal ${ }^{\circledR}$, Byk Gulden, Germany). Blood samples were taken before injection and 7, 14, 25, 33, 49, 121, 145, 169, 193 and 217 hours after injection.

\section{Measurement of the ${ }^{3} \mathrm{H}_{2} \mathrm{O}$ radioactivity}

The rabbit plasma $(200 \mu \mathrm{l})$ was added to $10 \mathrm{ml}$ Ready Gel (Beckman Instruments, Inc.) in glass vials, briefly mixed, $800 \mu 10.125$ $\mathrm{mol} / 1 \mathrm{HCl}$ solution added, mixed until clear and measured in a liquid scintillation counter (LSC $6000 \mathrm{SC}$, Low Level Version, Beckman Instruments, Inc.). The error of the measure was $2 \%$, the counting time 200 minutes.

\section{Gel permeation chromatography}

Chromatography of $\left[{ }^{3} \mathrm{H}\right.$ ]hyaluronan and plasma samples was performed on a Sepharose CL-6B column $(20 \mathrm{~mm} \times 500 \mathrm{~mm})$ equilibrated with $0.01 \mathrm{~mol} / 1$ phosphate buffer ( $\mathrm{pH} \mathrm{7.4)} \mathrm{containing} 0.15$ $\mathrm{mol} / 1 \mathrm{NaCl}$ and $0.2 \mathrm{~g} / 1 \mathrm{NaN}_{3}$. Void volume of the column $\left(\mathrm{V}_{\mathrm{o}}\right)$ was determined by Dextran Blue 2000, the total volume $\left(V_{t}\right)$ by $\mathrm{K}_{3}\left[\mathrm{Fe}(\mathrm{CN})_{6}\right]$

\section{Results}

Kinetics of the elimination of $\left[{ }^{3} \mathrm{H}\right]$ hyaluronan from normal rabbit knee joints determined from the decrease of $\left[{ }^{3} \mathrm{H}\right]$ hyaluronan content of synovial fluid (method I)

Measured ${ }^{3} \mathrm{H}$ activities $(\mathrm{kBq} / \mathrm{l})$ of synovial fluids harvested 12, 24 and 48 hours after intra-articular injection of $\left[{ }^{3} \mathrm{H}\right]$ hyaluronan are given in table 1 . Since the dilution method reveals both the volume of synovial fluid and the dilution factor of the aspirated mixture of hydroxyethyl starch solution and joint fluid, the $\left[{ }^{3} \mathrm{H}\right]$ hyaluronan content of the joint fluid was calculated (tab. 1).

The semilogarithmic plot of the $\left[{ }^{3} \mathrm{H}\right]$ hyaluronan content versus time after intra-articular administration reveals the mono-exponential decline in radioactivity characteristic of first-order kinetics (fig. 1) which is described by the relationship

$$
\frac{\mathrm{dX}}{\mathrm{dt}}=-\mathrm{k}_{\mathrm{HA}} \cdot \mathrm{X}
$$

where $X$ is the amount of $\left[{ }^{3} \mathrm{H}\right]$ hyaluronan $(\mathrm{Bq})$ in the joint fluid at time $t$ after injection. The term $k_{\mathrm{HA}}$ is the apparent first-order elimination rate constant for hyaluronan. After Laplace transformation (20) the equation is

$$
\log \mathrm{X}=\log \mathrm{X}_{\mathrm{o}}-\frac{\mathrm{k}_{\mathrm{HA}} \cdot \mathrm{t}}{2.303}
$$

$\mathrm{X}_{\mathrm{o}}$ represents the amount of $\left[{ }^{3} \mathrm{H}\right]$ hyaluronan injected into the joint cavity.

Although the rabbits in table 1 exhibit differing synovial fluid volumes, the semilogarithmic plot of $\left[{ }^{3} \mathrm{H}\right]$ hyaluronan content of the three rabbits was consistently linear over time indicating precise following of formulation in equation [2]. In contrast to the $\left[{ }^{3} \mathrm{H}\right]$ hyaluronan content versus time plot, the $\left[{ }^{3} \mathrm{H}\right]$ hyaluronan concentration $(\mathrm{kBq} / \mathrm{l})$ can only be plotted versus time if all synovial fluid volumes are identical.

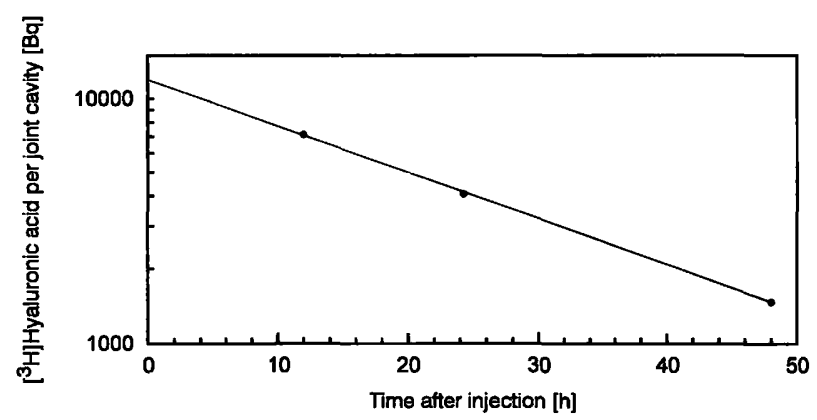

Fig. 1 Time course of $\left[{ }^{3} \mathrm{H}\right]$ hyaluronan content of the joint following intra-articular injection of $\left[{ }^{3} \mathrm{H}\right]$ hyaluronan (method $\mathrm{I}$ ). Correlation coefficient $r=-0.97$. 
The elimination rate constant $\mathrm{k}_{\mathrm{HA}}$ can be calculated from the slope of the $\log \mathrm{Bq} / \mathrm{joint}$ versus time plot (fig. 1) that is equal to $-\mathrm{k}_{\mathrm{HA}} / 2.303$. The constant $\mathrm{k}_{\mathrm{HA}}$ expresses the fraction of the original amount of injected $\left[{ }^{3} \mathrm{H}\right]$ hyaluronan that is removed in unit time $\left(\mathrm{h}^{-1}\right): \mathrm{a} \mathrm{k}_{\mathrm{HA}}$ value of $0.0438 / \mathrm{h}$ represents a turnover of $4.38 \%$. The half-life of the $\left[{ }^{3} \mathrm{H}\right]$ hyaluronan is obtained from the relationship

$$
\mathrm{t}_{1 / 2}=\ln 2 / \mathrm{k}_{\mathrm{HA}} \text {. }
$$

The kinetic values can also be calculated by the Pharmacokinetic and Pharmacodynamic Data Analysis System TOPFIT (21) using the non-compartmental analysis (values see tab. 2).

Kinetics of the elimination of $\left[{ }^{3} \mathrm{H}\right]$ hyaluronan from rabbit knee joints determined by following the ${ }^{3} \mathrm{H}_{2} \mathrm{O}$ activity of the blood (method II) after intra-articular injection

$\left[{ }^{3} \mathrm{H}\right]$ Hyaluronan injected intra-articularly enters the blood in a first-order kinetic. After entering the blood, the tritium of the acetyl groups is quickly metabolized in the liver overwhelmingly to ${ }^{3} \mathrm{H}_{2} \mathrm{O}$. The ${ }^{3} \mathrm{H}$ activity of the blood rises to $c_{\max }$ at time $t_{\max }$ and decreases monoexponentially (fig. 2). The term $t_{\max }$ is solely a function of $\mathrm{k}_{\mathrm{HA}}$ and the elimination rate constant $\mathrm{K}_{\mathrm{e}}$ of the ${ }^{3} \mathrm{H}_{2} \mathrm{O}$ (20). The ascending part of the curve (fig. 2) represents the elimination of $\left[{ }^{3} \mathrm{H}\right]$ hyaluronan from the joint cavity into the blood (rise of ${ }^{3} \mathrm{H}_{2} \mathrm{O}$ activity in blood) and the descending curve represents the elimination of ${ }^{3} \mathrm{H}_{2} \mathrm{O}$ from the blood $\left(\mathrm{K}_{e}\right)$ into urine and faeces. The elimination rate constant $K_{e}$ for plasma ${ }^{3} \mathrm{H}_{2} \mathrm{O}$ can be calculated from the slope $\left(-\mathrm{K}_{\mathrm{e}} /\right.$ 2.303) of the descending straight curve. The corresponding constants for the elimination of $\left[{ }^{3} \mathrm{H}\right]$ hyaluronan $\left(k_{\mathrm{HA}}\right)$ from the knee joints were derived by loglinear regression from the differences (residual values) between the observed levels of plasma ${ }^{3} \mathrm{H}$ activity (ascending curve) at each time point and the corresponding values from backward extrapolation of the regressions for ${ }^{3} \mathrm{H}_{2} \mathrm{O}(6,20,22)$. The residual concentrations of the $\left[{ }^{3} \mathrm{H}\right]$ hyaluronan in the joint cavity were semilogarithmically plotted versus time after injection (fig. 3), and $\mathrm{k}_{\mathrm{HA}}$ was calculated from the slope $\left(-\mathrm{k}_{\mathrm{HA}} /\right.$ 2.303) of the straight line. Application of the method of residuals is only possible if $\mathrm{k}_{\mathrm{HA}}>\mathrm{K}_{\mathrm{e}}(20)$. The

Tab. 2 Kinetics of $\left[{ }^{3} \mathrm{H}\right]$ hyaluronan elimination determined from the decrease of the $\left[{ }^{3} \mathrm{H}\right]$ hyaluronan content of synovial fluid in normal rabbit knee joints (method I).

\begin{tabular}{lll}
\hline $\mathrm{k}_{\mathrm{HA}}$ & $\begin{array}{l}\mathrm{t}_{1 / 2} \\
{\left[\mathrm{~h}^{-1}\right]}\end{array}$ & $\begin{array}{l}\mathrm{MRT}_{0-\infty} \\
{[\mathrm{h}]}\end{array}$ \\
\hline 0.0438 & 15.8 & 23.8 \\
\hline
\end{tabular}

$\mathrm{k}_{\mathrm{HA}}$ : elimination rate constant for synovial $\left[{ }^{3} \mathrm{H}\right]$ hyaluronan. $t_{1 / 2}:$ half-life. $\mathrm{MRT}_{0-\infty}$ : mean residence time. half-life of $\left[{ }^{3} \mathrm{H}\right]$ hyaluronan in the rabbit knee joint was obtained from the relationship $t_{1 / 2}=\ln 2 / \mathrm{k}_{\mathrm{HA}}$.

The kinetic terms $k_{H A}, t_{1 / 2}$, and mean residence time can also be calculated by the TOPFIT program assuming a one compartment disposition and one segment absorption. Using this method, we obtained the same values as with the residual's method.

Kinetics of the elimination of $\left[{ }^{3} \mathrm{H}\right]$ hyaluronan from normal, sham-operated, and osteoarthritic rabbit knee joints

Results obtained for the elimination of $\left[{ }^{3} \mathrm{H}\right]$ hyaluronan from the joint cavity for the different groups are given in table 3. Statistical analysis was performed employing the non-parametric Kruskal-Wallis test (program SPSS). Results of the statistical evaluation are shown in table 4. Half-lives of $\left[{ }^{3} \mathrm{H}\right]$ hyaluronan determined in the knee joints of all animals are compiled in figure 4. Half-life of hyaluronan, mean residence time and $t_{\max }$ were significantly higher in the osteoarthritis group "4 weeks after operation" (developing osteoarthritis) than in the group of non-operated animals (tab. 4) and achieved normal values 12 weeks after the operation (developed osteoarthritis). The differences between the group of non-operated control animals and the osteoarthritis group " 12 weeks after operation" were not significant (tab. 4). Differences between the sham-operated group and the osteoarthritis group "4

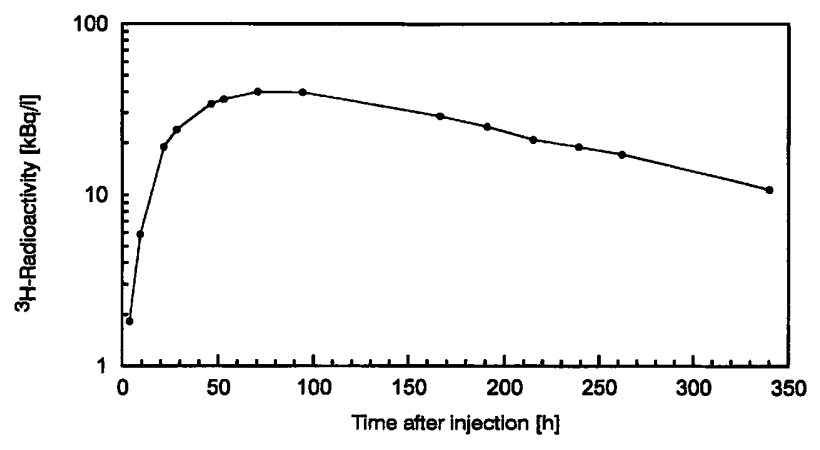

Fig. 2 Time course of ${ }^{3} \mathrm{H}$ radioactivity in plasma following intraarticular injection of $\left[{ }^{3} \mathrm{H}\right]$ hyaluronan (method II).

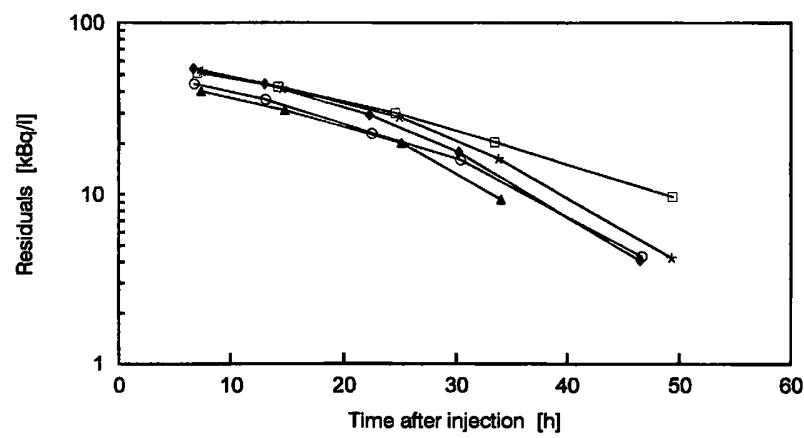

Fig. 3 Elimination of $\left[{ }^{3} \mathrm{H}\right]$ hyaluronan from the synovial cavity of non-operated control animals determined according to the method of residuals. 
Tab. 3 Kinetics of $\left[{ }^{3} \mathrm{H}\right]$ hyaluronan elimination from normal and injured rabbit knee joints estimated by following plasma ${ }^{3} \mathrm{H}$ radioactivity after intra-articular injection.

Values are given as mean \pm SEM.

\begin{tabular}{|c|c|c|c|c|c|c|}
\hline $\begin{array}{l}\text { Experimental } \\
\text { group }\end{array}$ & $\begin{array}{l}\mathrm{k}_{\mathrm{HA}} \\
{\left[\mathrm{h}^{-1}\right]}\end{array}$ & $\begin{array}{l}t_{1 / 2} \\
{[h]}\end{array}$ & $\begin{array}{l}t_{\max } \\
{[h]}\end{array}$ & $\begin{array}{l}\mathrm{MRT}_{0-x} \\
{[\mathrm{~h}]}\end{array}$ & $\begin{array}{l}\text { Clearance } \\
{[\mu \mathrm{l} / \mathrm{h}]}\end{array}$ & $\begin{array}{l}\text { Volume of } \\
\text { synovial fluic } \\
{[\mu \mathrm{l}]}\end{array}$ \\
\hline Non-operated & $\begin{array}{l}0.0402 \pm 0.0024 \\
n=5\end{array}$ & $\begin{array}{l}17.48 \pm 1.04 \\
\mathrm{n}=5\end{array}$ & $\begin{array}{l}60.64 \pm 1.52 \\
n=5\end{array}$ & $\begin{array}{l}29.70 \pm 2.03 \\
n=5\end{array}$ & $\begin{array}{l}18.0 \\
\mathrm{n}=2\end{array}$ & $\begin{array}{l}433 \pm 28 \\
\mathrm{n}=5^{\mathrm{a}}\end{array}$ \\
\hline Sham-operated & $\begin{array}{l}0.0401 \pm 0.0080 \\
\mathbf{n}=3\end{array}$ & $\begin{array}{l}18.80 \pm 3.67 \\
\mathrm{n}=3\end{array}$ & $\begin{array}{l}59.47 \pm 13.52 \\
\mathbf{n}=3\end{array}$ & $\begin{array}{l}35.00 \pm 5.17 \\
n=3\end{array}$ & $\begin{array}{l}27.2 \pm 7.1 \\
\mathrm{n}=3\end{array}$ & $\begin{array}{l}719 \pm 108 \\
n=6^{a}\end{array}$ \\
\hline $\begin{array}{l}\text { Four weeks after } \\
\text { operation }\end{array}$ & $\begin{array}{l}0.0306 \pm 0.0025 \\
n=5\end{array}$ & $\begin{array}{l}23.52 \pm 2.09 \\
\mathrm{n}=5\end{array}$ & $\begin{array}{l}76.76 \pm 7.63 \\
\mathrm{n}=5\end{array}$ & $\begin{array}{l}38.76 \pm 3.12 \\
n=5\end{array}$ & $\begin{array}{l}29.1 \\
\mathrm{n}=2\end{array}$ & $\begin{array}{l}938 \pm 209 \\
\mathrm{n}=4^{\mathrm{a}}\end{array}$ \\
\hline $\begin{array}{l}\text { Twelve weeks } \\
\text { after operation }\end{array}$ & $\begin{array}{l}0.0444 \pm 0.0061 \\
n=6\end{array}$ & $\begin{array}{l}17.38 \pm 2.66 \\
n=6\end{array}$ & $\begin{array}{l}57.30 \pm 6.87 \\
n=6\end{array}$ & $\begin{array}{l}29.08 \pm 4.12 \\
n=6\end{array}$ & $\begin{array}{l}33.1 \pm 5.6 \\
n=6\end{array}$ & $\begin{array}{l}844 \pm 345 \\
n=6\end{array}$ \\
\hline
\end{tabular}

$\mathrm{k}_{\mathrm{HA}}$ : elimination rate constant for synovial $\left[{ }^{3} \mathrm{H}\right]$ hyaluronan.

$t_{1 / 2}:$ half-life. $M T_{0-\infty}$ : mean residence time.

a Additional values for the calculation of an average volume were

$t_{\max }$ : time of the maximum plasma ${ }^{3} \mathrm{H}$ radioactivity. taken from a similar experiment.

Tab. 4 Statistical evaluation using the Kruskal-Wallis test. Differences between the groups were considered significant if the $\mathrm{p}$ value was lower than 0.05 (in bold).

\begin{tabular}{|c|c|c|c|c|c|}
\hline Comparison between the groups & $\begin{array}{l}\mathrm{k}_{\mathrm{HA}} \\
{\left[\mathrm{h}^{-1}\right]}\end{array}$ & $\begin{array}{l}t_{1 / 2} \\
{[h]}\end{array}$ & $\begin{array}{l}\mathrm{t}_{\max } \\
{[\mathrm{h}]}\end{array}$ & $\begin{array}{l}\mathrm{MRT}_{0-x} \\
{[\mathrm{~h}]}\end{array}$ & $\begin{array}{l}\text { Volume of } \\
\text { synovial fluid } \\
{[\mu \mathrm{l}]}\end{array}$ \\
\hline Non-operated/4 weeks after operation & 0.028 & 0.028 & 0.028 & 0.047 & 0.014 \\
\hline Non-operated/sham operation & 0.882 & 0.882 & 0.882 & 0.456 & 0.045 \\
\hline Four weeks $/ 12$ weeks after operation & 0.068 & 0.068 & 0.083 & 0.068 & 0.670 \\
\hline Non-operated/12 weeks after operation & 0.715 & 0.715 & 0.855 & 0.648 & 0.045 \\
\hline Sham-operation/4 weeks after operation & 0.297 & 0.297 & 0.297 & 0.655 & 0.286 \\
\hline
\end{tabular}

weeks after operation" were not significant due to the high variance and low animal number in the shamoperated group. It was remarkable that one animal of the sham-operated group, which also had elevated half-life, $t_{\max }$ and mean residence time, did not use his sham-operated leg to walk. Histological examination revealed no osteoarthritic changes in the articular cartilage layer of this leg.

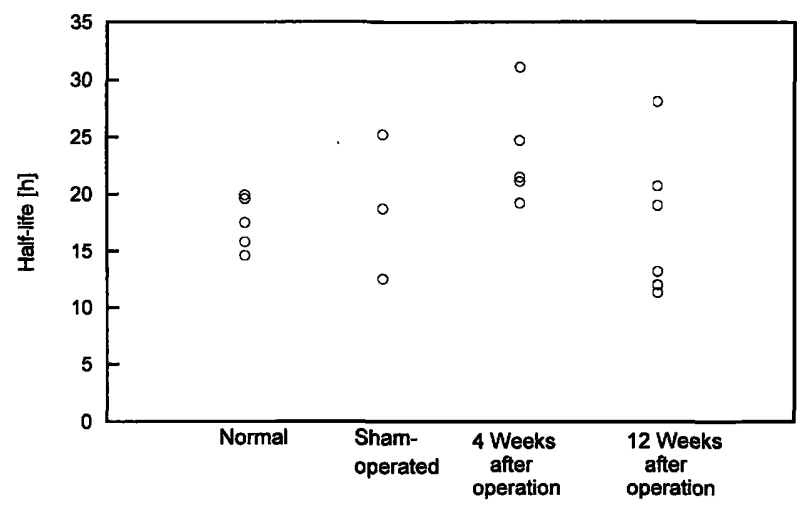

Fig. 4 Scattergrams of half-life of $\left[{ }^{3} \mathrm{H}\right]$ hyaluronan in normal and injured rabbit knee joints.

\section{Elimination of ${ }^{3} \mathrm{H}_{2} \mathrm{O}$ from blood}

The mean values for the kinetic terms of the several groups are given in table 5. The mean half-life of plasma ${ }^{3} \mathrm{H}_{2} \mathrm{O}$ did not differ significantly between the groups.

\section{Histological findings}

The opening of the joint capsule in the sham-operated group caused a slight disorganization of chondrocytes in comparison to the contralateral non-operated knee joint.

At 4 weeks post-surgery, the cartilage layer was characterized by slight fibrillations, a heavy disorganization of chondrocytes, clones near the articular surface and some fissures. The cartilage layer was very rich in cells. Only one animal of this group showed a partial erosion of the cartilage layer. At 12 weeks after surgery the alterations were more pronounced. The cartilage layer displayed fibrillations, disorganization of cells and deep clefts, but only one animal showed areas where the bone was denuded.

At 6 weeks after surgery, the synovium showed a low hyperplasia and a slight cell infiltration. In addition, 12 
Tab. 5 Kinetics of elimination of ${ }^{3} \mathrm{H}_{2} \mathrm{O}$ from blood. Values are given as mean $\pm \mathrm{SEM}$.

\begin{tabular}{lllll}
\hline & Group & & \\
\cline { 2 - 5 } & Non-operated & Sham-operated & $\begin{array}{l}\text { Four weeks after } \\
\text { operation }\end{array}$ & $\begin{array}{l}\text { Twelve weeks after } \\
\text { operation }\end{array}$ \\
\hline $\mathrm{K}_{\mathrm{e}}\left[\mathrm{h}^{-1}\right]$ & $0.0054 \pm 0.0005$ & $0.0064 \pm 0.0005$ & $0.0050 \pm 0.0002$ & $0.0051 \pm 0.0004$ \\
$\mathrm{t}_{1 / 2}[\mathrm{~h}]$ & $132.4 \pm 13.5$ & $110.4 \pm 9.6$ & $138.0 \pm 5.8$ & $138.5 \pm 10.8$ \\
\hline
\end{tabular}

$\mathrm{K}_{\mathrm{e}}$ : elimination rate constant of ${ }^{3} \mathrm{H}_{2} \mathrm{O}$ from blood.

weeks after injury, the synovium was only slightly hyperplastic.

\section{Size-exclusion chromatography of}

\section{$\left[{ }^{3} \mathrm{H}\right]$ hyaluronan and plasma samples}

Synthesized $\left[{ }^{3} \mathrm{H}\right]$ hyaluronan eluted together with Blue Dextran 2000 (average $M_{\mathrm{r}} 2 \cdot 10^{6}$ ) at the void volume of the Sepharose CL-6B column (fig. 5). Since the approximate exclusion limit of Sepharose CL-6B for polysaccharides is given as $1 \cdot 10^{6}\left(M_{\mathrm{r}}\right)$, the $\left[{ }^{3} \mathrm{H}\right]$ hyaluronan synthesized in cell culture was of high molecular mass. Brown et al. determined a $M_{\mathrm{r}}$ of about $6 \cdot 10^{6}$ for $\left[{ }^{3} \mathrm{H}\right] \mathrm{Hy}-$ aluronan synthesized by human synovial cells (6). After enzymatic digestion with hyaluronidase from Streptomyces hyalurolyticus, the ${ }^{3} \mathrm{H}$ activity appeared entirely at $\mathrm{V}_{\mathrm{t}}$ of the column (fig. 5). In concordance with the fact that hyaluronan is rapidly degraded in lymph nodes and in liver to yield mainly ${ }^{3} \mathrm{H}_{2} \mathrm{O}$, the plasma ${ }^{3} \mathrm{H}$ activity appeared for the most part at $\mathrm{V}_{\mathrm{t}}$, consistent with the behaviour of ${ }^{3} \mathrm{H}_{2} \mathrm{O}$. Separating rabbit plasma, we obtained different results. In some rabbits we still found a small ${ }^{3} \mathrm{H}$ activity at $\mathrm{V}_{\mathrm{o}}$ nine hours after injection (fig. 6). Forty-six hours after injection (fig. 7), the peak at $V_{0}$ was considerably lower, but rose again 214 hours after injection (fig. 8). To decide whether the peak at $\mathrm{V}_{\mathrm{o}}$ contained $\left[{ }^{3} \mathrm{H}\right]$ hyaluronan, the void volume peak was incu-

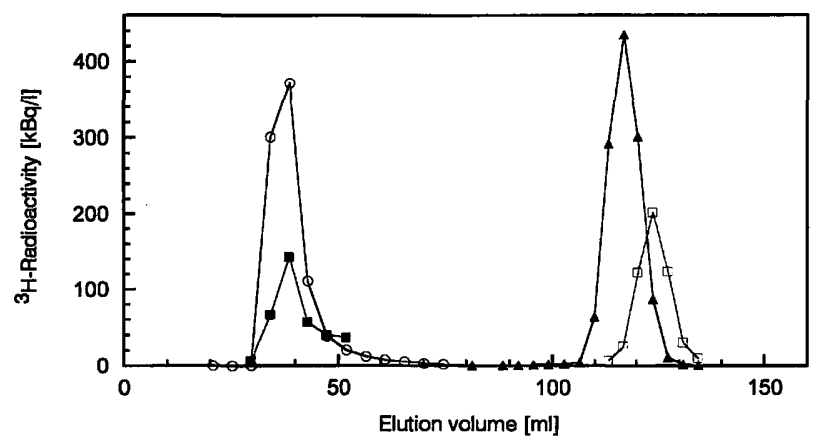

Fig. 5 Size-exclusion chromatography of $\left[{ }^{3} \mathrm{H}\right]$ hyaluronan on Sepharose CL-6B.

$0,4.3 \mathrm{kBq}\left[{ }^{3} \mathrm{H}\right]$ hyaluronan separated on the column;

$\Delta, 4.3 \mathrm{kBq}\left[{ }^{3} \mathrm{H}\right]$ hyaluronan digested with hyaluronidase from Streptomyces hyalurolyticus and analyzed on the column;

a, absorbance of Dextran Blue 2000 was measured at $625 \mathrm{~nm}$, that of $\mathrm{K}_{3}\left[\mathrm{Fe}(\mathrm{CN})_{6}\right](\square)$ at $410 \mathrm{~nm}$.

Eluant: $0.1 \mathrm{~mol} / 1$ phosphate buffer, $0.15 \mathrm{~mol} / 1 \mathrm{NaCl}, 0.2 \mathrm{~g} / 1 \mathrm{NaN}_{3}$, pH 7.4; applied sample volume: $1 \mathrm{ml}$; recovered fractions: $4 \mathrm{ml}$; elution rate: $12 \mathrm{ml} / \mathrm{h}$.

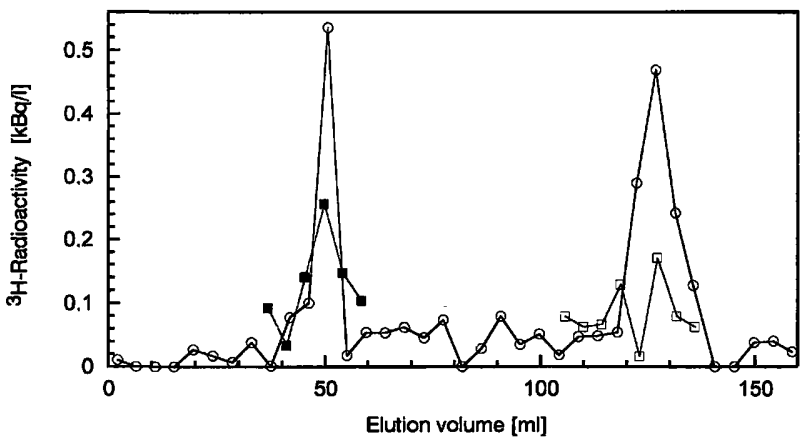

Fig. 6 Size-exclusion chromatography on Sepharose CL-6B of rabbit plasma (osteoarthritis group "4 weeks after operation"). Blood was taken 9 hours after intra-articular injection of $\left[{ }^{3} \mathrm{H}\right]$ hyaluronan.

$0,{ }^{3} \mathrm{H}$ radioactivity of the elution fractions;

a, Dextran Blue 2000;

$\square, \mathrm{K}_{3}\left[\mathrm{Fe}(\mathrm{CN})_{6}\right]$.

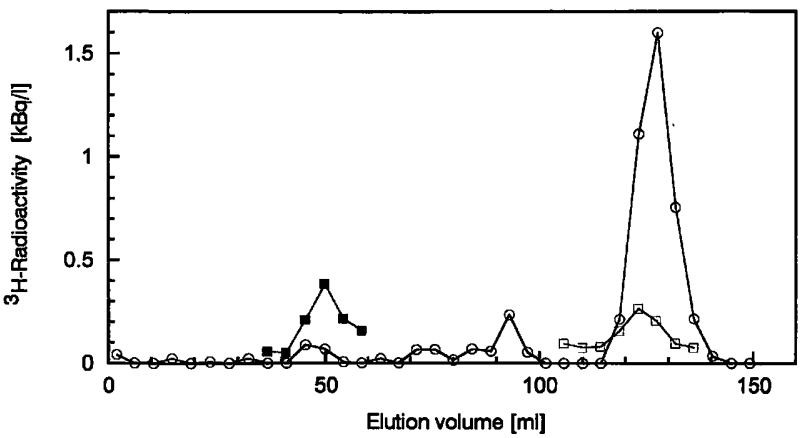

Fig. 7 Size-exclusion chromatography on Sepharose CL-6B of rabbit plasma (osteoarthritis group "4 weeks after operation"). Blood was taken 46 hours after intra-articular injection of $\left[{ }^{3} \mathrm{H}\right]$ hyaluronan.

$0,{ }^{3} \mathrm{H}$ radioactivity of the elution fractions;

a, Dextran Blue 2000;

$\square, \mathrm{K}_{3}\left[\mathrm{Fe}(\mathrm{CN})_{6}\right]$.

bated with hyaluronidase from Streptomyces hyalurolyticus and analyzed again by size-exclusion chromatography on Sepharose. The void volume peak was completely eliminated and appeared at $V_{t}$ (fig. 9). This indicates that a small part of ${ }^{3} \mathrm{H}$-labelled acetyl groups is possibly reutilized for the synthesis of lipid or other substances (22), may be even of hyaluronan.

\section{Hyaluronan analysis}

Hyaluronan concentration and content of the synovial fluids are compiled in table 6. Using the Kruskal-Wallis 


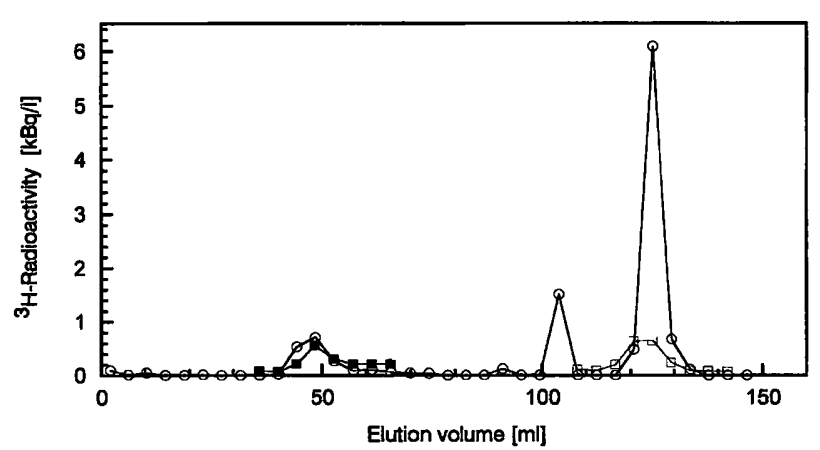

Fig. 8 Size-exclusion chromatography on Sepharose CL-6B of rabbit plasma (osteoarthritis group "4 weeks after operation").

Blood was taken 214 hours after intra-articular injection of $\left[{ }^{3} \mathrm{H}\right]$ hyaluronan.

$0,{ }^{3} \mathrm{H}$ radioactivity of the eluation fractions;

口, Dextran Blue 2000;

$\square, \mathrm{K}_{3}\left[\mathrm{Fe}(\mathrm{CN})_{6}\right]$.

test for statistical evaluation we found a significantly lower hyaluronan concentration in the osteoarthritis group " 4 weeks after operation" in comparison to the osteoarthritis group " 12 weeks after operation", whereas hyaluronan content of the osteoarthritis group " 4 weeks after operation" was significantly higher than that of the group of non-operated animals.

\section{Discussion}

After intra-articular injection of small amounts of $\left[{ }^{3} \mathrm{H}\right]$ hyaluronan, the kinetics of hyaluronan elimination from the joint can be estimated

(i) by following the $\left[{ }^{3} \mathrm{H}\right]$ hyaluronan content of the joint fluid after intra-articular injection or

(ii) by following ${ }^{3} \mathrm{H}$ activity in blood after intra-articular injection (6).

Using both methods, we obtained a half-life of 15.8 hours and $\mathbf{1 7 . 5}$ hours, respectively, for normal rabbit knee joints. These values are on the same order of magnitude as those found by Brown et al. ( $\mathrm{t}_{1 / 2}=13.2$ hours, method II, (6)). There are two differences between the investigations:

(i) we used synovial cells from rabbits for the $\left[{ }^{3} \mathrm{H}\right]$ hyaluronan synthesis, Brown et al. used synovial cells of human origin and

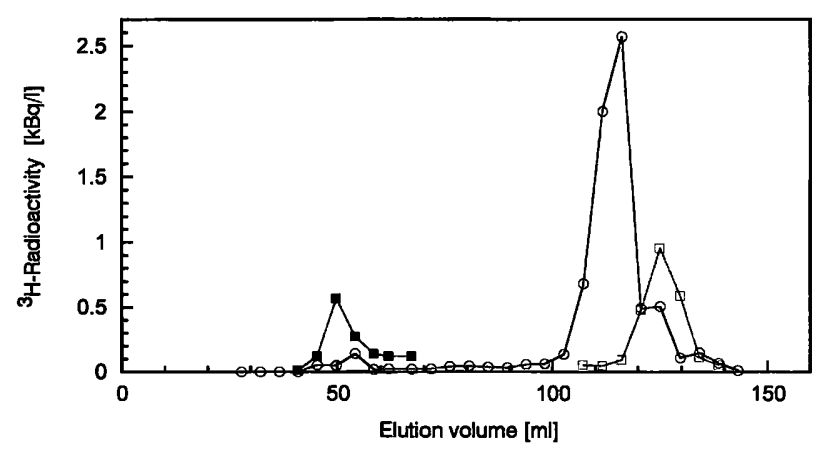

Fig. 9 Size-exclusion chromatography on Sepharose CL-6B of the void volume fraction, containing ${ }^{3} \mathrm{H}$ radioactivity, after digestion with hyaluronidase from Streptomyces hyalurolyticus.

$\mathrm{O},{ }^{3} \mathrm{H}$ radioactivity of the eluation fractions;

口, Dextran Blue 2000;

$\square, \mathrm{K}_{3}\left[\mathrm{Fe}(\mathrm{CN})_{6}\right]$.

(ii) we used chinchilla rabbits whereas Brown et al. used English lop-eared rabbits. We suppose that the differences in hyaluronan half-life reflect breed-related variations.

Four weeks after surgery, during the phase of developing osteoarthritis, the half-life of hyaluronan rose significantly to 23.5 hours and returned to normal levels 12 weeks after operation (developed osteoarthritis). Similarly $t_{\max }$ and mean residence time were enhanced 4 weeks after operation and dropped to normal levels 12 weeks after operation. Correspondingly, the fractional turnover rate of hyaluronan $\left(\mathrm{k}_{\mathrm{HA}} \cdot 100\right)$ was lowered from $4.02 \%$ to $3.06 \%$ during the phase of developing osteoarthritis but was not significantly different from the non-operated control group in the phase of developed osteoarthritis.

We suppose that changes in the synovium might be responsible for the elevated half-life of hyaluronan because high molecular mass compounds, such as hyaluronan and proteoglycans, leave the joint through the intercellular space and the lymphatic endothelium $(5,6)$. Therefore, alterations of the synovium such as thickening, inflammation, hyperplasia or accumulation of hyaluronan at the lining layer may influence the passage of hyaluronan into the lymphatic vessels and thus cause a change of half-life of hyaluronan. But we found only mild inflammatory signs and hyperplasia of the synov-

Tab. 6 Hyaluronan concentration and content of synovial fluids of normal and injured rabbit knee joints. Values are given as mean $\pm \mathrm{SEM}$.

\begin{tabular}{lllll}
\hline & Non-operated group & Sham-operated group & $\begin{array}{l}\text { Osteoarthritis group } \\
\text { "4 weeks after } \\
\text { operation" }\end{array}$ & $\begin{array}{l}\text { Osteoarthritis group } \\
\text { "12 weeks after } \\
\text { operation" }\end{array}$ \\
\hline $\begin{array}{l}\text { Hyaluronan concentration } \\
\text { [g/l] }\end{array}$ & $\begin{array}{l}2.04 \pm 0.19 \\
\mathrm{n}=6\end{array}$ & $\begin{array}{l}1.99 \pm 0.31 \\
\mathrm{n}=3\end{array}$ & $\begin{array}{l}1.61 \pm 0.07 \\
\mathrm{n}=4\end{array}$ & $\begin{array}{l}2.27 \pm 0.13 \\
\mathrm{n}=3\end{array}$ \\
$\begin{array}{l}\text { Hyaluronan content } \\
\text { [mg/synovial fluid] }\end{array}$ & $\begin{array}{l}0.91 \pm 0.09 \\
\mathrm{n}=6\end{array}$ & $\begin{array}{l}1.65 \pm 0.73 \\
\mathrm{n}=3\end{array}$ & $\begin{array}{l}1.53 \pm 0.36 \\
\mathrm{n}=4\end{array}$ & $\begin{array}{l}2.01 \pm 0.95 \\
\mathrm{n}=3\end{array}$ \\
\hline
\end{tabular}


ium, so that the reason for the half-life elevation in the phase of developing osteoarthritis remains unclear.

The enhanced values of half-life of hyaluronan in the phase of the developing osteoarthritis cannot be explained by the surgery because 2 out of 3 animals in the sham-operated group showed normal half-lives. However, as a response to the sham operation (4 weeks after operation), the volume of the synovial fluid in the shamoperated knee joints was higher than in the knee joints of the non-operated control animals (see tab. 3 ).

Heilmann et al. obtained similar results using aminopyridine- and fluoresceine-labelled hyaluronan (unpublished results). Fluorescence-labelled hyaluronan had a considerably lower intra-synovial half-life than $\left[{ }^{3} \mathrm{H}\right]$ hyaluronan, which can be partially explained by the lower $M_{\mathrm{r}}$ in comparison to the high molecular mass $\left[{ }^{3} \mathrm{H}\right]$ hyaluronan. Using fluorescence-labelled hyaluronan, Heilmann et al. also found elevated half-lives in the rabbit osteoarthritis model of Colombo et al. (unpublished results). However, the half-lives can only be determined by following the content of fluorescence-labelled hyaluronan in the joint cavity (method I) because the fluorescent marker is quickly destroyed outside of the joint and therfore is not detectable in the blood.

In interpreting clearance studies, both half-life as well as intra-articular fluid volume, in which the injected $\left[{ }^{3} \mathrm{H}\right]$ hyaluronan was distributed, must be taken into consideration $(23,24)$, because the clearance rate of hyaluronan (volume of joint fluid cleared in unit time) depends not only on the rate constant $\mathrm{k}_{\mathrm{HA}}$ (or $\mathrm{t}_{1 / 2}$ ) but also on volume (clearance rate $=\mathrm{k} \times$ distribution volume). If the volume of synovial fluid is enhanced, then the mechanism removing hyaluronan from the joint must have been enhanced. Whereas $\mathrm{k}_{\mathrm{HA}}$ of normal and osteoarthritic rabbit knee joints did not differ significantly at the stage of developed osteoarthritis (tab. 4), the clearance rates of the osteoarthritis group were considerably higher in comparison to the non-operated control group (tab. 3) due to the significantly higher synovial fluid volumes of the osteoarthritis group (tab. 4).

The clearance of low molecular mass components such as iodide ( $\mathrm{t}_{1 / 2}: 0.6$ to 1.3 hours) is interpreted as a measure of synovial plasma flow, whereas the clearance of high molecular mass compounds such as albumin $\left(t_{1 / 2}: 8\right.$ to 17 hours), hyaluronan ( $t_{1 / 2}: 11$ to 31 hours) or proteoglycan ( $t_{1 / 2}: 12$ to 17 hours) is considered as representing the rate of lymphatic drainage from the joint $(6,25)$. Brown et al. already suggested a common pathway for the elimination of hyaluronan and proteoglycan monomers from the joint cavity because of the striking similarity between their half-lives (6).

Clearance and half-life of different high molecular mass compounds were determined by several authors under conditions of low and high grade synovitis. Myers et al. provoked a mild synovitis by injection of $0.05 \mu \mathrm{g}$ calcium pyrophosphate crystals into canine knee!joints (26) and found an increased albumin clearance but no changed half-life of albumin, whereas in acute synovitis induced by injection of $0.5 \mu \mathrm{g}$ or $500 \mu \mathrm{g}$ of calcium pyrophosphate a marked decrease of half-life was observed. Since Myers et al. presented only clearance values of their experiments, we calculated the corresponding half-lives from data given in their publication. PageThomas et al. determined the half-life of ${ }^{131}$ I-labelled proteoglycan subunit in rabbit knee joints with and without experimental arthritis (27). They found a half-life of $12.94 \pm 0.63$ hours for normal joints and a not significantly altered half-life in the presence of an active synovitis (14.49 \pm 2.58 hours). Fraser et al. reported a gross reduction in the half-life of hyaluronan in synovial fluid in acute monoarticular arthritis induced by intra-articular injection of type II collagen into sheep hock joints (22). The half-life fell from $20.8 \pm 1.8$ hours to $11.5 \pm 1.1$ hours (mean \pm SEM) with a corresponding increase in mean fractional hyaluronan turnover from $3.5 \%$ /hour to $6.3 \% /$ hour. We suppose that the half-life of high molecular compounds in the joint seems not to be altered under conditions of a low grade synovitis, as seen in the rabbit model of osteoarthritis or in the model of Myers et al. (26), whereas under inflammatory conditions the halflife is grossly reduced. At present we do not know the reason for the elevated half-life of hyaluronan in the osteoarthritis model of Colombo et al. when osteoarthritis is developing.

Our investigation was done with regard to an early diagnosis of osteoarthritis, which is urgently needed. Such investigations can be carried out on human beings only on a very limited scale, thus animal models have to be used. In contrast to human osteoarthritis, animal models of osteoarthritis allow the development of the disease in a relatively short time, enable pathophysiologic and pathobiochemical investigations of joint components and allow it to follow the process of the disease accurately. We chose the rabbit model of osteoarthritis because meniscectomy and ligament damage result in progressive degenerative changes of the joint which are similar to that in human osteoarthritis. It has to be proven whether the estimation of half-life of hyaluronan in the joint fluid will be of any value to the early diagnosis of human osteoarthritis.

It is difficult to discuss the hyaluronan concentrations of the synovial fluids in our groups (tab. 6) because hyaluronan concentration depends on different factors:

(i) synthesis by the lining cells,

(ii) half-life of hyaluronan in the joint fluid and

(iii) hyaluronan accumulation in the joint. 
Hyaluronan presumably accumulates in the joints during rest and is removed by physical exercise (7). In the normal joint the main deposit seems to be in the lining layer while in the swollen inflamed synovium the hyaluronan is distributed throughout the perivascular spaces (7). Therefore, we are not able to answer the question of why the hyaluronan concentration is decreased in osteoarthritis although hyalukonan synthesis is enhanced by osteoarthritic synovium and the half-life of hyaluronan is increased and unchanged,

\section{References}

1. Balazs EA, Denlinger JL. Viscosupplementation: a new concept in the treatment of osteoarthritis. J Rheumatol 1993; 20 Suppl 39:3-9.

2. Peyron JG. A new approach to the treatment of osteoarthritis: viscosupplementation. Osteoarthritis Cartilage 1993; 1:85-7.

3. Dougados M, Nguyen M, Listrat V, Amor B. High molecular weight sodium hyaluronate (hyalectin) in osteoarthritis of the knee: a 1 year placebo-controlled trial. Osteoarthritis Cartilage 1993; 1:97-103.

4. Pelletier JP, Martel-Pelletier J. The pathophysiology of osteoarthritis and the implication of the use of hyaluronan and hylan as therapeutic agents in viscosupplementation. J Rheumatol 1993; 20 Suppl 39:19-24.

5. Antonas KN, Fraser JRE, Muirden KD. Distribution of biologically labelled radioactive hyaluronic acid injected into joints. Ann Rheum Dis 1973; 32:103-11.

6. Brown TJ, Laurent UBG, Fraser JRE. Turnover of hyaluronan in synovial joints: elimination of labelled hyaluronan from the knee joint of the rabbit. Exp Physiol 1991; 76:125-34.

7. Laurent TC, Fraser JRE, Laurent UBG, Engström-Laurent A. Hyaluronan in inflammatory joint disease. Acta Orthop Scand 1995; 66 Suppl 266:116-20.

8. Fraser JRE, Laurent TC, Pertoft H, Baxter E. Plasma clearance, tissue distribution and metabolism of hyaluronic acid injected intravenously in the rabbit. Biochem J 1981; 200:415-24.

9. Laurent TC, Fraser JRE. Hyaluronan. FASEB J 1992; 6:2397-404.

10. Lebel L, Gabrielsson J, Laurent TC, Gerdin B. Kinetics of circulating hyaluronan in humans. Eur J Clin Invest 1994; 24:621-6.

11. Heilmann HH, Lindenhayn K, Walther HU. Das Synovia-Volumen gesunder und arthrotischer menschlicher Kniegelenke. Z Orthop 1996; 134:144-8.

12. Myers SL, Brandt KD. Studies of synovial hyaluronic acid synthesis in canine osteoarthritis. J Rheumatol 1987; $14: 1150-5$.

13. Manicourt DH, Cornu O, Lenz ME, Druetz-van Egeren A, Thonar EJM. Rapid and sustained rise in the serum level of hyaluronan after anterior cruciate ligament transection in the dog knee joint. J Rheumatol 1995; 22:262-9.

14. Colombo C, Butler M, O'Byrne EA. New model of osteoarthritis in rabbits. I. Development of knee joint pathology following lateral meniscectomy and section of the fibular col- respectively. In the rabbit model of Colombo et al. the hyaluronan concentrations seem to be lowered at the stage of developing osteoarthritis but not at the stage of developed osteoarthritis.

\section{Acknowledgements}

The authors would like to thank Dr. Donath of the Institute of Clinical Pharmacology (Medical School, Charité) for introducing them to pharmacokinetic calculations using the computer program TOPFIT.

lateral and sesamoid ligaments. Arthritis Rheum 1983; 26:875-86.

15. Romeis B, Böck P. Mikroskopische Technik. 17th ed. München, Wien, Baltimore: Urban and Schwarzenberg, 1989:499-500.

16. Heilmann $\mathrm{HH}$. Investigations for the development of a biochemical joint function test. Acta Biol Hung 1984; 35:315-23.

17. Levick JR, McDonald JN. Fluid movement across synovium in healthy joints: role of synovial fluid macromolecules. Ann Rheum Dis 1995; 54:417-23.

18. Jourdian GW, Wolfman M, Sarber R, Distler J. A specific, sensitive method for the determination of hyaluronate. Anal Biochem 1979; 96:474-80.

19. Ohya T, Kaneko Y. Novel hyaluronidase from Steptomyces. Biochim Biophys Acta 1970; 198:607-9.

20. Gibaldi M, Perrir D. Pharmacokinetics. 2nd ed. New York, Basel: Marcel Dekker, 1982:1-42.

21. Heinzel G, Woloszczak R, Thomann P. Topfit. Pharmacokinetic and pharmacodynamic data analysis system for the PC. Stuttgart, Jena, New York: Gustav Fischer, 1993.

22. Fraser RE, Kimpton WG, Pierscionek BK, Cahill RNP. The kinetics of hyaluronan in normal and acutely inflamed synovial joints: observations with experimental arthritis in sheep. Semin Arthritis Rheum 1993; 22 Suppl 1:9-17.

23. Levick JR, Thompson PW. Intra-articular volume as an important factor governing macromolecular half life in synovial fluid. Ann Rheum Dis 1988; 47:701-2.

24. Wallis WJ, Simkin PA, Nelp WB, Foster DM. Intraarticular volume and clearance in human synovial effusions. Arthritis Rheum 1985; 28:441-9.

25. Simkin PA, Benedict RS. Iodide and albumin kinetics in normal canine wrists and knees. Arthritis Rheum 1990; 33:73-9.

26. Myers SL, Brandt KD, Eilam O. Even low-grade synovitis significantly accelerates the clearance of protein from the canine knee. Implications for measurement of synovial fluid "markers" of osteoarthritis. Arthritis Rheum 1995; 38:1085-91.

27. Page-Thomas DP, Bard D, King B, Dingle JT. Clearance of proteoglycan from joint cavities. Ann Rheum Dis 1987; 46:934-7.

Received July 17, 1996/March 5, 1997

Corresponding author: Dr. K. Lindenhayn, Orthopädische Klinik, Charité, Scharnhorststraße 3, D-10115 Berlin, Germany 
